\title{
CORRELATION OF THE STATE OF CRUSTAL STRESSES, SEISMICITY AND LANDSLIDE ACTIVITY (FERGANA BASIN, TIEN SHAN)
}

\author{
Z. A. Kalmet'eva, B. D. Moldobekov, U. A. Abdybachaev \\ Central-Asian Institute for Applied Geosciences, Bishkek, Kyrgyzstan
}

\begin{abstract}
The impacts of seismicity on the landslide activity in Kyrgyzstan have been in the focus of our study since 2010 [Kalmetyeva et al., 2010]. As the study progressed [Kalmetyeva, Moldobekov, 2012, 2013; Kalmetyeva et al., 2013, 2014], the initial problem statement has been revised as follows: do earthquake influence the occurrence of landslides, and, if so, what is the mechanism of this influence. This paper presents the results of detailed analysis of the distribution of earthquakes and landslides in space and time in correlation with focal mechanisms (azimuth and plunge of the principal compression stress axis) of earthquakes occurred in the Fergana basin and its mountainous frame. These are grounds to conclude that the landslide activity is mainly influenced by the response of the internal structure of the upper crust to local stresses. The mechanism of influence of strong earthquakes on the landslide activity is redistribution of local stresses, which results from partial release of regional stresses due to rupturing in the source zones of strong earthquakes. Using this concept of the landslide activity, a methodology of landslide-hazard mapping is the goal of our future studies aimed at the following: (1) zoning of the study area with respect to the features of the internal structure of the upper crust, (2) geological, geophysical and seismological studies of the state of stresses in the study area, (3) instrumental monitoring of landslides movements in the zones that differ in the structure of the upper crust, and (4) analysis of preparation and consequences of past strong earthquakes that took place in the study area in comparison with the landslide activity.
\end{abstract}

Key words: seismic cycle; earthquake; focal mechanism; main stress axes; landslide; atmospheric precipitation

For citation: Kalmet'eva Z.A., Moldobekov B.D., Abdybachaev U.A., 2019. Correlation of the state of crustal stresses, seismicity and landslide activity (Fergana basin, Tien Shan). Geodynamics \& Tectonophysics 10 (4), 995-1009. doi:10.5800/GT-2019-10-4-0454. 


\title{
СООТНОШЕНИЕ НАПРЯЖЕННОГО СОСТОЯНИЯ ЗЕМНОЙ КОРЫ, СЕЙСМИЧНОСТИ И ОПОЛЗНЕВОЙ АКТИВНОСТИ (НА ПРИМЕРЕ ФЕРГАНСКОЙ ВПАДИНЫ, ТЯНЬ-ШАНЬ)
}

\author{
3. А. Кальметьева, Б. Д. Молдобеков, У. А. Абдыбачаев
}

Центрально-Азиатский институт прикладных исследований Земли, Бишкек, Кыргызстан

\begin{abstract}
Аннотация: Наши исследования были начаты в 2010 году [Kalmetyeva et al., 2010] с целью изучения влияния сейсмичности на оползневую активность в Кыргызстане. Однако в процессе исследований [Kalmetyeva, Moldobekov, 2012, 2013; Kalmetyeva et al., 2013, 2014] формулировка поставленной изначально задачи несколько изменилась, а именно: влияют ли землетрясения на возникновение оползней и, если да, то каков механизм этого воздействия. Настоящее сообщение является завершающим в решении поставленной задачи. Приводятся результаты более детального рассмотрения пространственно-временного распределения оползней и землетрясений в сопоставлении с данными о механизмах очагов (азимут и угол погружения главной оси напряжения сжатия Р) этих землетрясений для территории Ферганской впадины и ее горного обрамления. Проведенный анализ позволяет сделать предположение, что решающее значение в оползневой активности имеет реакция внутренней структуры земной коры на локальные напряжения. Механизм воздействия сильных землетрясений на активизацию оползней состоит в перераспределении локальных напряжений, которое происходит в результате высвобождения некоторой части региональных напряжений, связанных с образованием разрыва в очаге сильного землетрясения. Такое представление об оползневой активности показывает, что основные направления исследований по разработке методики составления карт оползневой опасности должны состоять в следующем: районирование территории по внутренней структуре верхних частей земной коры (1), установка пунктов инструментальных наблюдений за движением оползней на участках территории с различающейся структурой верхних частей земной коры (2), изучение напряженного состояния территории методами геологии, геофизики, сейсмологии (3), анализ подготовки и последствий прошлых сильных землетрясений в сопоставлении с оползневой активностью (4).
\end{abstract}

Ключевые слова: сейсмический цикл; землетрясение; механизм очага землетрясения; главные оси напряжений; оползень; атмосферные осадки

\section{INTRODUCTION}

Initially, our study aimed at investigating the influence of earthquakes on the landslide activity. After considering the first results, doubts were cast upon the correctness of the problem statement. Instrumental observations were conducted on the Mailisai landslides located on opposite sides of the riverbed on the hill slopes that differ in aspect. It was revealed that, firstly, the landslides moved synchronously at all observation points (regardless of the aspect), and, secondly, the beginning of the landslide movements and the occurrence of microshocks (i.e. seismic activity) was also synchronous [Kalmetyeva et al., 2013]. This fact strongly suggested that both processes - landsliding and seismicity - were influenced by one and the same factor. Furthermore, instrumental observations of the Tuyuk-Suu landslide showed that the landslide body began to move a few days before the earthquake [Kalmetyeva et al., 2010]. Cases of massive landsliding in dry weather several days before strong earthquakes were described in [Meleshko et al., 2002; Torgoev et al., 2011; Niyazov,
Nurtaev, 2015; Niyazov, 2017]. Seismologists are aware of the fact that strong earthquakes are often preceded by an increase in the number of microshocks, and this phenomenon is considered as a short-term precursor of a strong earthquake. Massive landsliding in dry weather can be viewed as another short-term precursor of a devastating earthquake.

An important conclusion was made after correlating the earthquake focal mechanisms (EFM) with the landslide activity in the Northern Tien Shan [Kalmetyeva et al., 2010] - the landslide activity begins when, after some stabilization of horizontal compression (i.e. the $\mathrm{P}$-axis plunge in the EFM solutions remains subhorizontal for several months or longer, Plunge $\mathrm{P} \leq 20^{\circ}$ ), the $\mathrm{P}$-axis suddenly deviates from the horizontal position. According to the same data, the landslides generally become active only within a certain limited area, while the neighbouring areas remain inactive, despite the fact that conditions in these areas are apparently similar. It is noteworthy that the selectivity of the landslide locations is noted throughout the entire Tien Shan region [Strom et al., 2005]. In the Northern Tien Shan, the in- 
ternal structure of the upper crust is different in these areas [Kalmetyeva et al., 2014]. What is the role of these differences in the occurrence and activity of landslides?

According to [Kalmetyeva, Moldobekov, 2013], the above observations were generally valid for the Fergana basin and its mountainous frame, although the features of this area were much more complicated. Anyway, the mechanism of the impacts of seismicity on the landslide activity remained unclear. Furthermore, there were reasons to revise the initial problem statement as follows: do earthquake influence the occurrence of landslides, and, if so, what is the mechanism of this influence.

This paper presents the results for the Fergana basin and its mountainous frame, based on a more detailed analysis of the distribution of landslides and earthquakes in space and time in correlation with the focal mechanisms of earthquakes occured in this study area. Our study has clarified the relationship between the landslide activity and seismicity and revealed a possible mechanism of the landslide activity. The objective of further research is to specify the methodology of landslide hazard mapping.

\section{DATABASE}

In our study of the Fergana basin and its mountainous frame, the information on seismicity of the study area was taken from the earthquake catalogue published by the Institute of Seismology of the National Academy of Sciences of the Kyrgyz Republic [Abdrakhmatov et al., 2008], the 1960-1992 catalogues of EFM (authors N.Kh. Bagmanova, T.Ya. Belenovich and V.M. Slepoy), as well as the annual catalogs of EFM for 1995-2005, compiled in the IS NAS KR and published in the yearbook "Earthquake of Northern Eurasia". The database on large landslides included the data from [Ibatulin, 2011], and the field survey data from [Abdybachaev, 2015]. The precipitation records of the Hydrometeorological Agency of the Kyrgyz Republic were provided by 0 . Kalashnikova.

\section{BRIEF DESCRIPTION OF THE STUDY AREA}

The study was focused on the eastern part of the Fergana basin and its mountainous frame due to the following factors: high landslide activity, high population density, and the availability of the instrumental observation data on landslides (the latter being a critical factor for such studies).

The northern and southwestern regions of the Tien Shan differ in the geological history, velocity structure and seismic activity levels. Seismic activity of the Fergana basin is about three times higher than that of the
Northern Tien Shan. The number of earthquakes is significantly larger in the Fergana basin, but there have been no devastating earthquakes, in contrast to the Northern Tien Shan (e.g. Kemin and Suusamyr earthquakes in 1911 and 1992, respectively) [Seismic Zoning..., 1980].

According to the seismic tomography data, the deep structure to the west of the Talas-Fergana fault comprises the 'homogenous' mantle showing a gradual increase in seismic wave velocity with depth, and heterogeneities are located in the crust. In the Northern Tien Shan, on the contrary, there are no heterogeneities in the crust, while the mantle is highly heterogeneous [Bakirov, 2006]. Compared to the Chu basin (latitudinal strike of tectonic structures and active faults), the setting in this area is much more complicated. In the northern part of the mountainous frame of the Fergana basin, boundaries of 'stable' uplifts and subsidence zones (i.e. tectonic zones) follows the fault pattern. In the northeastern part, the boundaries go across active faults almost at an angle of $90^{\circ}$. In the Eastern and Southern parts of mountainous frame of the Fergana basin, the boundaries of tectonic zones are again spatially coincident with active faults. These regions of the Tien Shan differ in the geologic history. The Southwestern Tien Shan is under the influence of the PamirHimalaya collision, and its structure is predetermined by the rotation of the Fergana block, while the Central Tien Shan develops relatively autonomously under transpression [Mikolaichuk, 2009].

Even the spatial distribution of landslides is different in the Northern Tien Shan and the mountainous frame of the Fergana basin. In the Northern Tien Shan, large landslides are clearly confined to the faults bordering modern uplifts. In the mountainous frame of the Fergana basin, large landslides occur both at the boundaries of 'stable' uplifts and in other areas.

\section{SEISMICITY}

It is known that the seismic process is not stationary - it occurs in cycles. Cycles of 90-100, 45-50, 23-26 and 6-10 years are typical for the territory of Kyrgyzstan [Grin et al., 1980; Yudakhin, Kalmetyeva, 1994]. Earthquake data on the Fergana basin and its mountainous frame are given in Fig. 1, $a$.

Obviously, at different times the data available for the study area differ in the level of detail. Historical information on devastating earthquakes $\left(\mathrm{K} \geq 14\right.$ or $\mathrm{I}_{0} \geq 7$ in the MSK64 scale) is available only since 1880 . The first seismic station in Tashkent was installed and surveyed in 1911, and a catalog of earthquakes including $\mathrm{K}=13$ $\left(\mathrm{I}_{0}=5\right)$ events was consolidated. As the number of stations increased, the records of weaker events were catalogued: $K \geq 12$ since 1929 ; $K \geq 10$ since 1951 , and $K \geq 8$ 

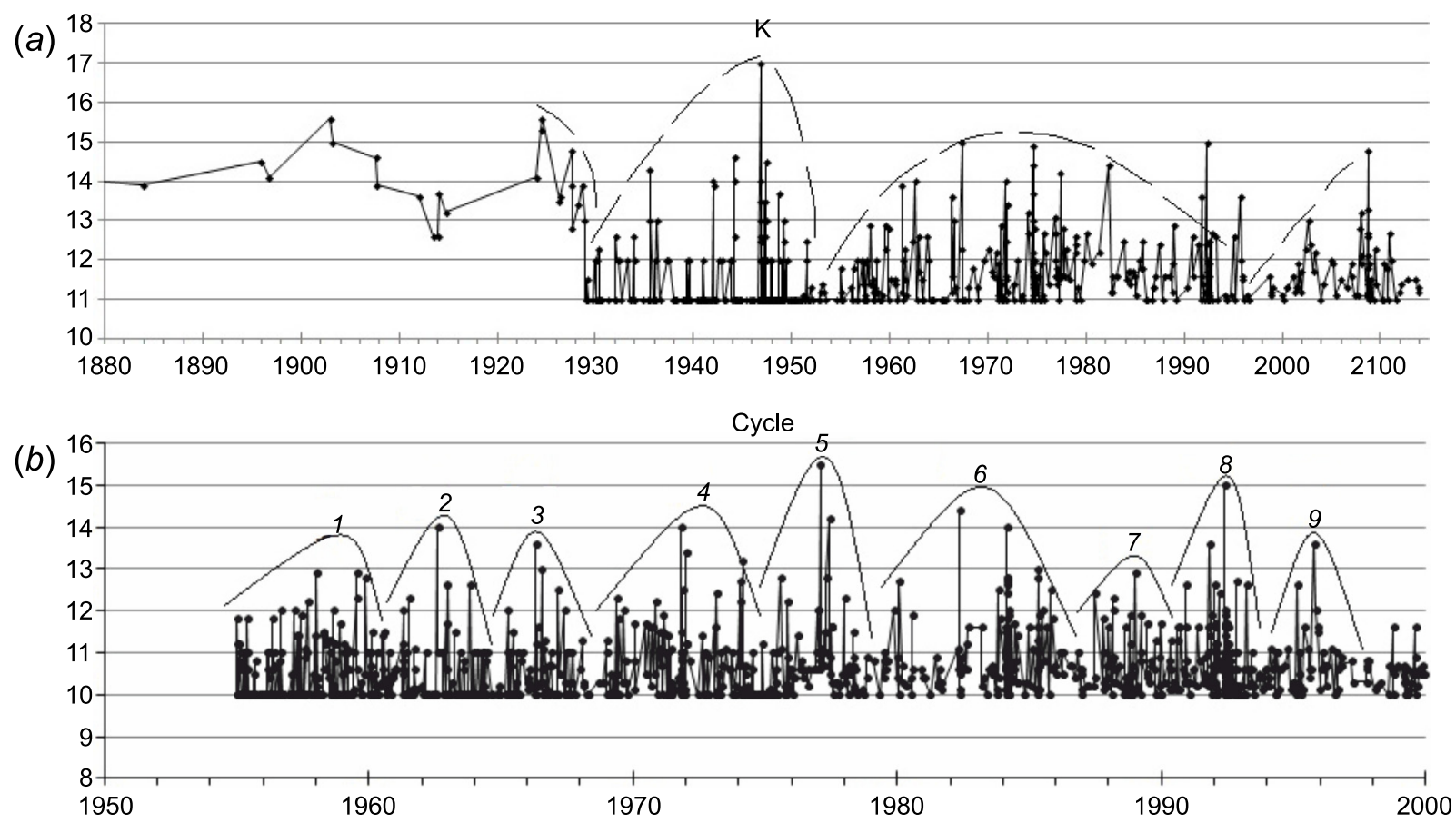

Fig. 1. Energy classes of earthquakes in the order of their occurrence ( $a$ - all the data for the study area; $b-50$-year cycle of 1950-2000), according to the Institute of Seismology of NAS KR [Abdrakhmatov et al., 2008].

Рис. 1. Энергетический класс землетрясений в порядке их возникновения ( $a$ - весь известный для исследуемой территории материал; $b$ - в течение 50-летнего цикла с 1950 по 2000 год) по данным Института сейсмологии НАН КР [Abdrakhmatov et al., 2008].

since 1974 [Seismic Zoning..., 1980]. Determination of focal mechanism solutions for $K \geq 9$ earthquakes were started in the late 1960s. Considering the availability of the data required for this study, a 50-year cycle of 19502000 was selected for analysis. This cycle is divided into nine 'seismic burst cycles' (hereafter bursts) (Fig. 1, b). Within each burst, the spatial patterns of earthquake epicenters and the spatial orientations of the compression (P) axis are analysed using the EFM data.

Fig. 2 shows the maps of earthquake epicenters for the nine bursts, and the azimuth-diagrams of the earthquakes quantity with the same AzP values. As they are the mostly weak events (K=9-10) so we also constructed azimuth-diagrams of strong $(K \geq 12)$ events (right).

The maps in Fig. $2(a, b, c, d, e, f, g, h, i)$ show that relatively strong earthquakes $(K \geq 12, M \geq 4.5)$ occurred along a straight line within one burst, and this is typical of almost all the bursts. These straight direction changes from one burst to another, and the P-axis direction also changes. In general, the submeridional $\mathrm{P}$ axis is characteristic of the entire Tien Shan territory. However, the $\mathrm{P}$ axis direction (especially the northern one) slightly changes from one burst to another - in the first three bursts of 1955-1968. (see Fig. 2, $a, b, c$ ), the directions migrate counterclockwise within the azimuths from 40 to $320^{\circ}$. The northward, southward, eastward and westward directions are observed in burst 4 (Fig.
$2, d)$, and the southern directions is dominant in burst 5 (Fig. 2,c). Later on, the northern directions again begin to slowly migrate counterclockwise (bursts 6, 7 and 8 , see Fig. $2, f, g, h)$ and again starting from the azimuth of $40^{\circ}$. The southern directions are slightly shifted to the east, in the range of $140-180^{\circ}$.

The migration lines of the epicenters of strong $(K \geq 12)$ earthquakes are generally consistent with the fault directions in the study area, except for those time periods when strong $(K \geq 12)$ earthquakes occurred with predominant compression from the south (bursts 3 and 5, see Fig. 2, $c, e$ ). Two strong earthquake occurred in burst 5 - 31.01.1977 Isfara-Batken $(\mathrm{K}=15.5$, $\left.\mathrm{M}=6.3, \mathrm{I}_{0}=7-8\right)$ and 03.06.1977 Khaidarken ( $\left.\mathrm{K}=14.2\right)$. The migration line of their epicenters goes at an angle across the line of the South Fergana fault system. In bursts 2 and 8 , the migration lines are sublatitudinal, and the P-axis is submeridional. In bursts 1 and 6 (1955-1960) and 1979-1986, respectively), the migration lines of the epicenters of strong earthquakes practically coincide, and the northward P-axis azimuths are also coincident $\left(20^{\circ}\right)$.

The above data suggest a relationship between the migration lines of earthquake epicenters and the spatial orientations of the compression (P) axis. Changes in the P-axis azimuth are accompanied by changes in the migration line of strong $(K \geq 12)$ earthquakes. 

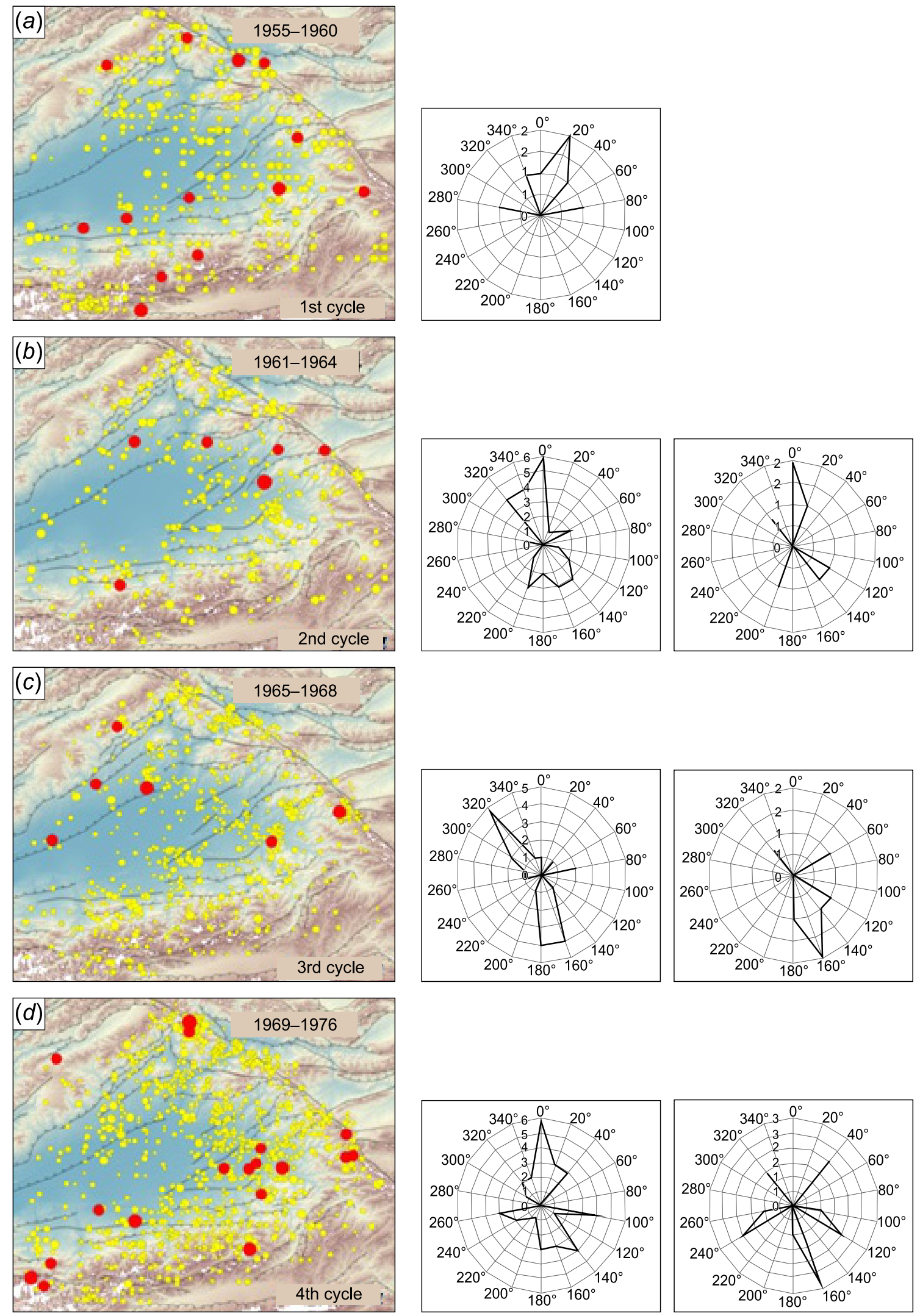

Fig. 2. Maps of earthquake epicenters and the azimuth-diagrams of AzP values for all earthquakes of the burst (center) and for $\mathrm{K} \geq 12$ earthquakes (right). Active faults after [Mikolaichuk, 2009]. Earthquake epicenters are marked by circles: red $\mathrm{K} \geq 12$; yellow $-\mathrm{K}<12$.

Рис. 2. Карты эпицентров землетрясений и диаграммы распределения количества землетрясений по азимуту оси сжатия Р (для всех землетрясений цикла - в центре и для землетрясений с К $\geq 12$ - справа). Активные разломы приведены по данным А.В. Миколайчука [Mikolaichuk, 2009]. Красные кружочки обозначают эпицентры землетрясений энергетического класса К $\geq 12$, желтые - К<12. 

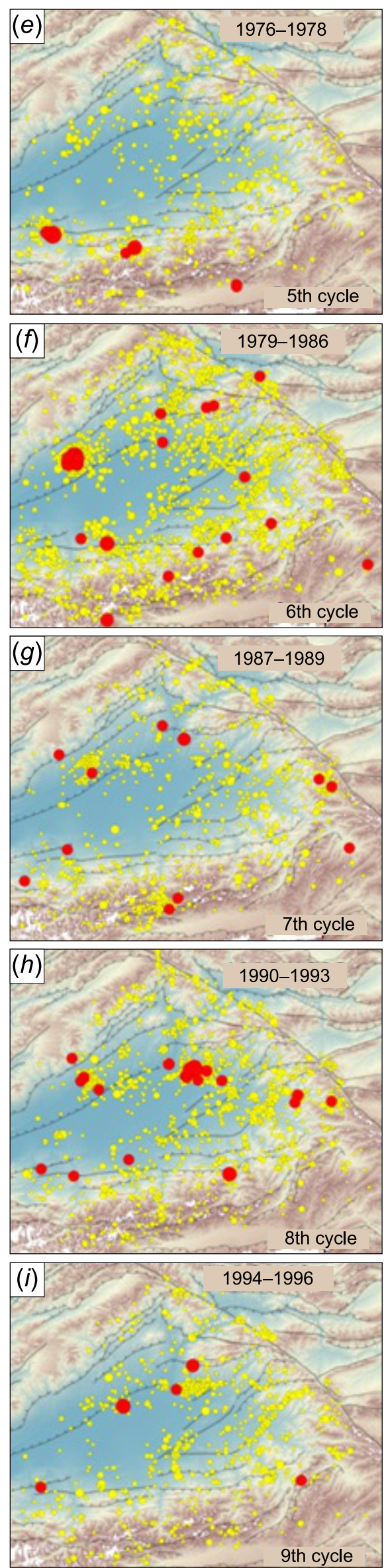
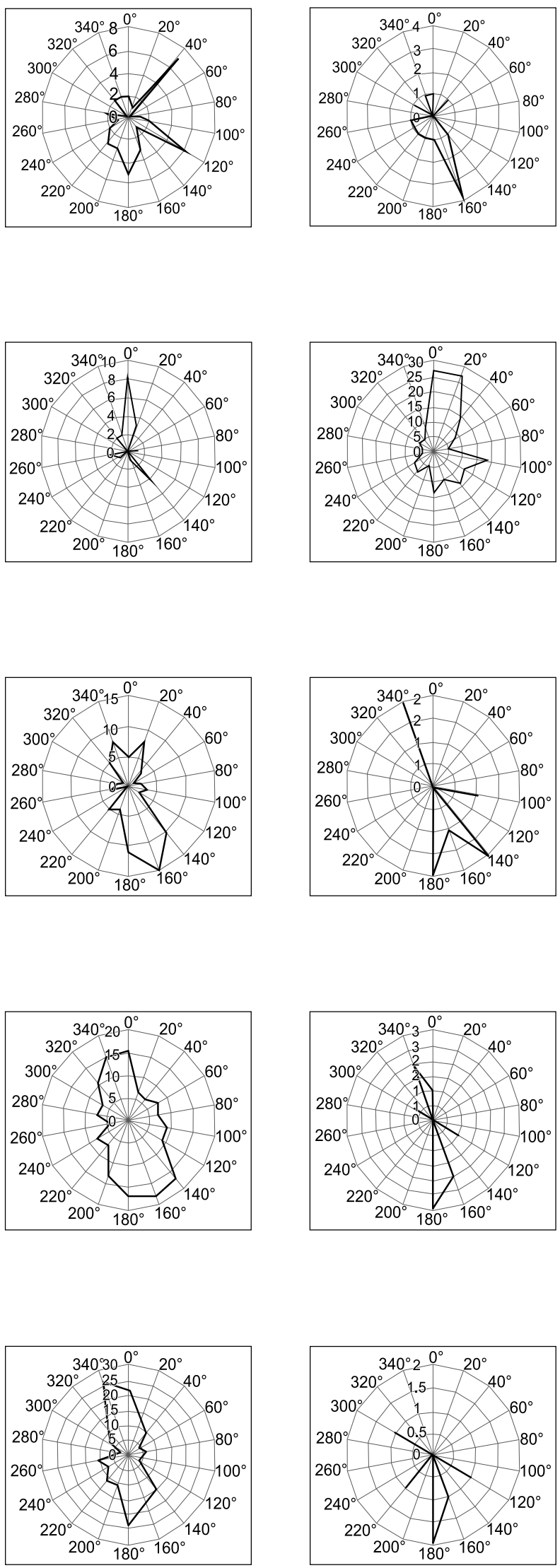

Fig. 2 (c o n t i n u e d).

Pис. 2 (о ко н ч а н и е). 


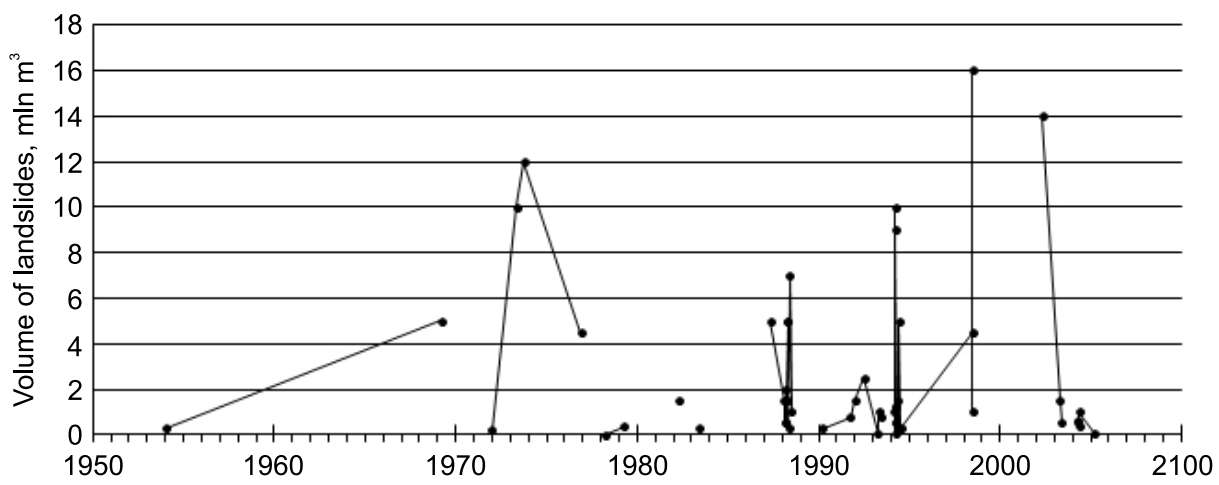

Fig. 3. Volumes of large landslides $\left(\mathrm{mln}^{3}\right)$ after [Ibatulin, 2011].

Рис. 3. Объем крупных оползней (млн м³) по данным [Ibatulin, 2011].

\section{LANDSLIDES}

Systematic surveys of landslides in Kyrgyzstan began in the mid-1950s to monitor and investigate numerous active landslides in the Mailisai area. In 1954, the Ministry of Emergency Situations of the Kyrgyz Republic established the Landslide Survey Department for the southern regions of Kyrgyzstan and installed the first landslide observation station in 1957. After the collapse of the USSR, this department gradually ceased to function. The descriptions of the major landslides and the history of landslide monitoring in Kyrgyzstan are available in [Ibatulin, 2011]. The volumes of large landslides and their occurrence dates are shown in Fig. 3 based on the data from [Ibatulin, 2011]. According to these data, two 50-year cycles can be distinguished in the landslide activity, seemingly similar to the seismic cycles (see Fig. 1, a), but these landslide activity cycles do not coincide with the seismic cycles. In 1978, the first landslide cycle ended, and the second one began. On the contrary, the seismic cycle of that time includes the strongest Isfara-Batken earthquake (burst 5, see Fig. 2, e). The second landslide cycle reached its peak in 1998, while the 50-year seismic cycle, on the contrary, was ended at that time. In other words, the 50-year seismic and landslide cycles are shifted relative to each other by 25 years.

The landslides are distributed unevenly in the study area (Fig. 4) - the densest clusters of small landslides are located at the lower reaches of the Kugart river and in the area south of the Kara-Daria river, and the largest landslides (12-16 $\mathrm{mln} \mathrm{m}^{3}$ ) are confined to these clusters. Several landslides are located at the fault lines and arranged in lines following the fault lines. Of interest is a chain of landslides between the Yassy and Kara-Daria rivers, which seems to mark the eastern boundary of the landslide-hazard areas.

The analysis of the landslide occurrence in space and time, shows that the landslides did not slide in the study area at the same time. Their clusters occurred on separate sites at different time intervals (Fig. 4). Site 1 is the Mailisai landslide cluster. Site 2 is the landslide cluster between the Kugart and Yassy rivers; this block is clearly distinguishable in the field - it is bordered by a thrust on the west and the Yassy river on the east. Site 3 is the largest one; its northern boundary is the Kara-Daria river.

The boundaries of 'stable' uplifts and 'stable' subsidence areas are shown in Fig. 4, $b$ [Chedia, 1986]. On Sites 1 and 2, the landslides are located along the boundaries of 'stable' uplifts. On Site 3, most of the landslides are located in the area between the boundaries of 'stable' uplifts and 'stable' subsidence areas, wherein uplifting commenced in the Quaternary period and replaced the Paleogene-Neogene subsiding [Chedia, 1986].

Migration of large landslides in time is illustrated in Fig. 5 based on the EFM solutions and landslide data published in [Ibatulin, 2011]. Plunge P vs. time graphs are constructed for the three sites. Red rhombs show large landslides $\left(\mathrm{V} \geq 300000 \mathrm{~m}^{3}\right)$; the largest landslide is $16 \mathrm{mln} \mathrm{m}^{3}$. The time of occurrence of the strongest earthquakes is marked by blue lines.

In the analyzed period of time, the first large landslides occurred only on Site 1. In 1973, the landslide activity ceased on Site 1, but developed more actively on Site 2 that remained active until 1978. Later on, large landslides occurred on Site 3, and the volume of landslides gradually increased with time. In 19921995, the whole northeastern boundary of the Fergana basin became active and then landslides did not occur at all on Site 1 and 2. On Site 3, on the contrary the landslide activity continued to increase, and two huge landslides slid down(14 and $16 \mathrm{mln} \mathrm{m}^{3}$ ).

Three aspects of the landslide activity in the study area are revealed by the analysis of the times of occurrence and locations of landslides in correlation with the EFM data (see Fig. 2 and Fig. 5). Firstly, the vast majority of landslides occurred when the P-axis angle to the horizontal plane was significant (in other words, when the side support was reduced] [Postoev, 2010; Postoev, 

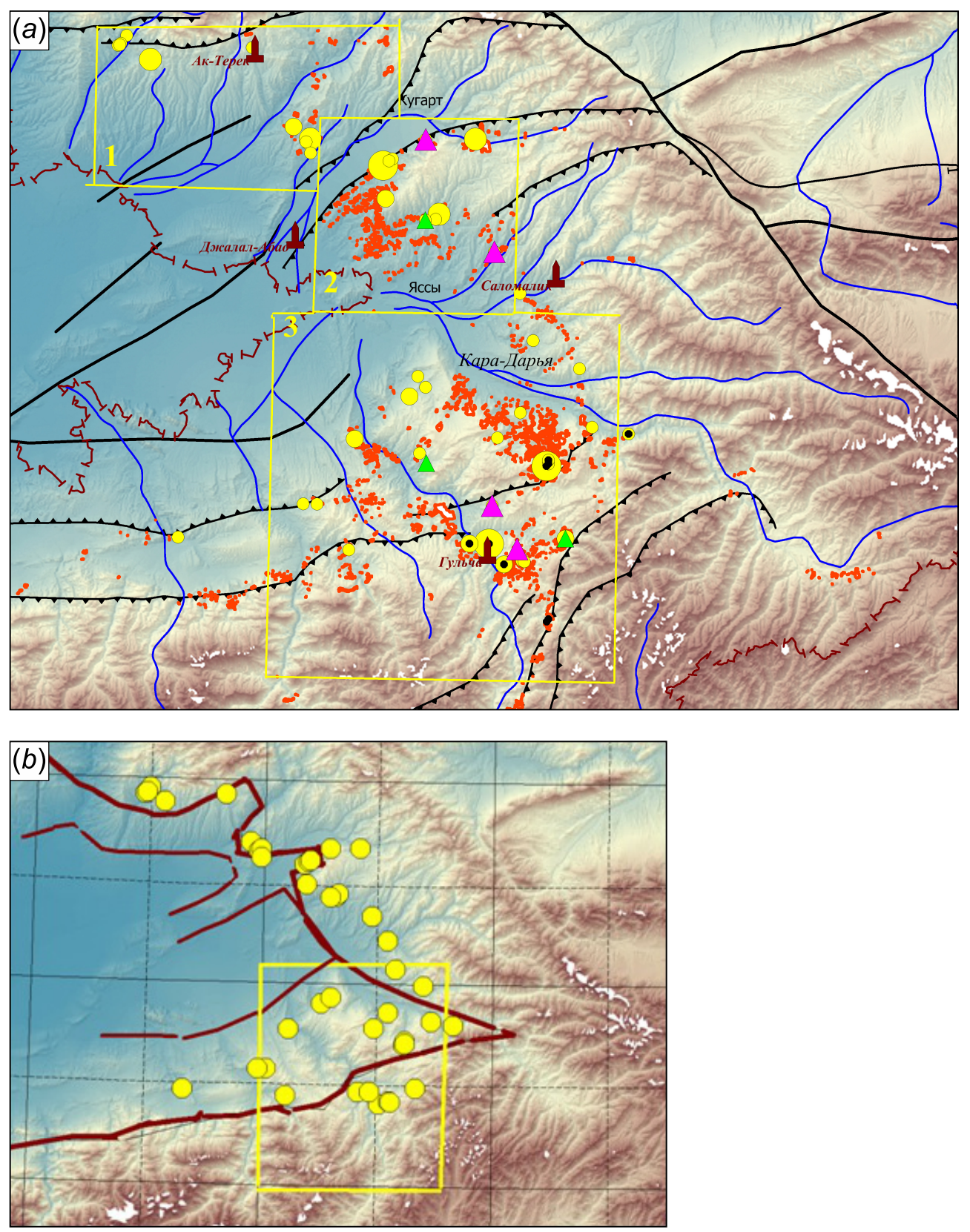

Fig. 4. Map of landslides: $(a)$ - red dots - locations of landslides according to the field survey database of U.A. Abdybachaev. Yellow circles - large (V $\geq 0.3 \mathrm{mln} \mathrm{m}^{3}$ ) landslides after [Ibatulin, 2011]. Black circles inside yellow circles - landslides formed over the ancient landslide bodies. Green triangles - areas with numerous new landslide fractures. Pink triangles - rapid landslides that developed at catastrophic rates (above $3 \mathrm{~m} / \mathrm{sec}$ ). Active faults after [Mikolaichuk, 2009]. (b) - wide line boundaries of 'stable' uplifts; narrow line - boundaries of 'stable' subsidence areas after [Chedia, 1986].

Рис. 4. Карта оползней. Желтые кружочки показывают местоположение крупных (V $\geq 0.3$ млн м³) оползней по данным [Ibatulin, 2011]; черными кружочками внутри желтых кружочков отмечены оползни, сошедшие на телах древних оползней. Зеленые треугольники показывают участки, где образовалось большое количество новых оползневых трещин. Розовыми треугольниками обозначены скоростные оползни (сходившие с катастрофической скоростью, более 3 м/с). Активные разломы по данным [Mikolaichuk, 2009].

Kazeev, 2011]. In 1984-1987, the position of the P-axis was horizontal, and no large landslides went down on any of the three sites. Secondly, on Sites 1 and 2, landsliding was active primarily when the position of the $P$ axis was submeridional (see Fig. 2), whereas on Site 3, the landsliding activity increased when domi- nant compression was only from the south or only from the north. Can this be indicative of a relationship between the landslide activity on a particular site and the P-axis azimuth (AzP) on the given site? And, thirdly, the impact of strong earthquake radiation needs to be considered. 

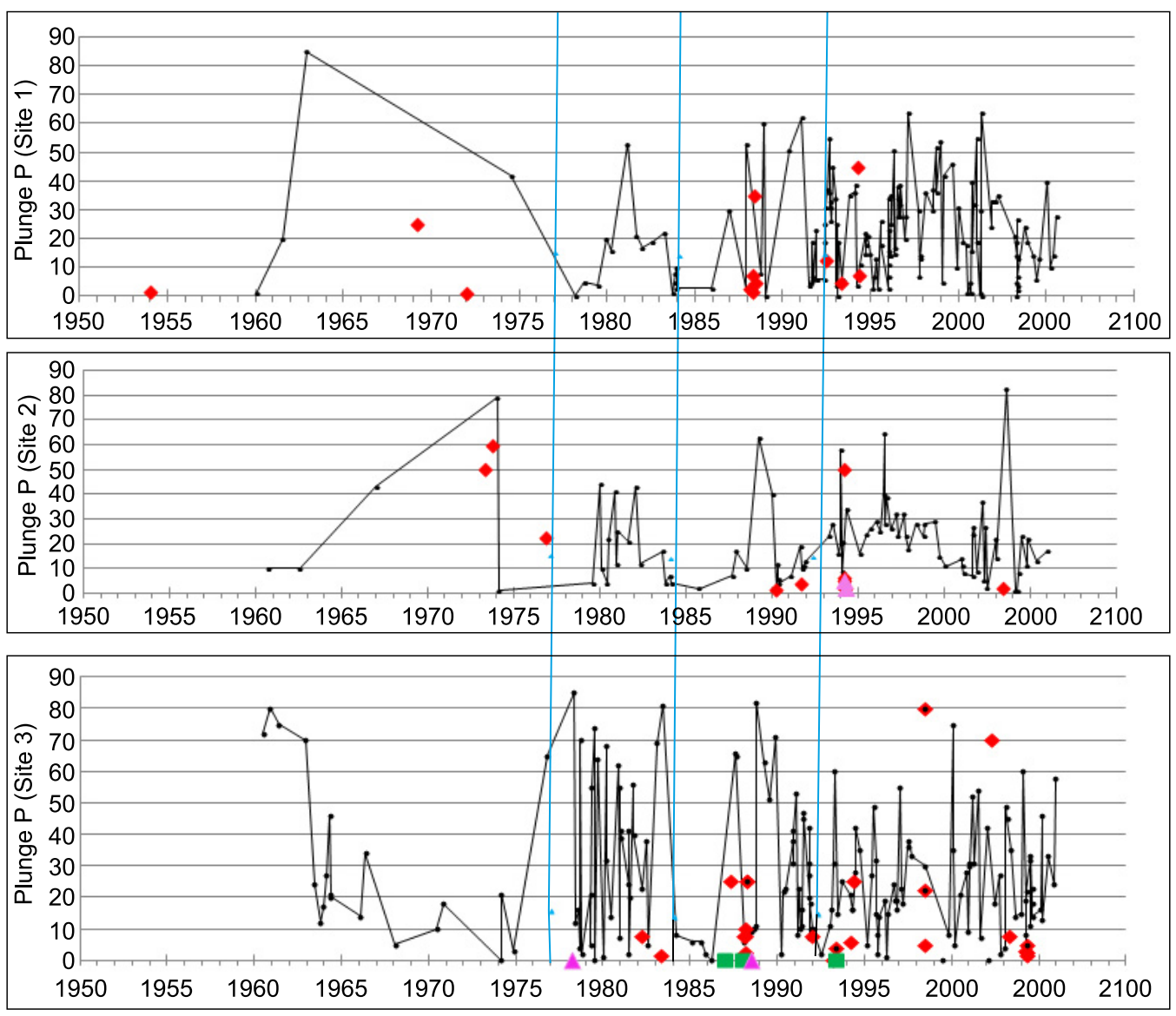

| Fig. 5. Plunge P vs. time graphs for the three sites. See the legend in Fig. 4, $a$. Explanations in the text.

Рис. 5. График изменения во времени угла погружения оси Р в пределах трех площадок. Обозначения те же, что на рис. $4, a$. Пояснения в тексте.

In 1977, the Isfara-Batken earthquake ( $\mathrm{K}=15.5$, $\mathrm{M}=6.3, \mathrm{I}_{0}=7-8$ ) triggered the landslide activity on Site 3 - the maximum seismic radiation propagated to the northeast, i.e. towards Site 3, according to the EFM (Fig. 6, $a$, Fig. 7) and macroseismic survey data [Kalmetyeva et al., 2009]. The first landslide event at Site 3 occurred in the Ken-Zhylga village on the April 4, 1978. This unusual landslide is termed shooter in [Ibatulin, 2011] - the $7.0 \mathrm{~m}^{3}$ landslide rapidly moved down the hell slope for over $30 \mathrm{~m}$ and hit the opposite bank of the river. It should be noted that the mountain range can 'shoot' boulders during strong earthquakes. This phenomenon was observed during, for example, the Kemin (1911) and Suusamyr (1992) earthquakes. In his study of the Kemin earthquake, K.I. Bogdanovich put emphasis on this phenomenon and suggested that 'shooting' of rock segments and stones can results from of the passage of intense elastic waves, rather than from displacements of the rock mass itself [Bogdanovich et al., 1911]. Most probably, a shooter landslide is caused by the same factors.

The next major seismic event was the Papskoe earthquake $\left(\mathrm{K}=14, \mathrm{M}=5.5, \mathrm{I}_{0}=8\right)$ on February 17, 1984.
It was accompanied by numerous foreshocks and aftershocks and thus resembled a swarm of earthquakes. Most of the earthquake sources were located on the northern uplifted wing of the North Fergana fault. Having originated from the northeastern part of the epicentral area, the seismic process rapidly developed towards the southwest [Gafurov, 1986], i.e. the maximum seismic radiation was outside the territory under consideration. This earthquake is a specific marker after its occurrence, the P-axis took the horizontal position on all the three above-mentioned sites for several years, and no large landslides occurred during that period.

The Kochkorata earthquake ( $\left.\mathrm{K}=15, \mathrm{M}=6.3, \mathrm{I}_{0}=8\right)$ occurred on May 15, 1992. According to the EFM (see Fig. 6, c) and macroseismic survey data [Dzhanuzakov et al., 2003], its maximum destruction zone stretched in the latitudinal direction, with the highest attenuation rates observed in the northwest direction. Due to such seismic radiation, the landslide activity increased on all the three sites.

These aspects of seismic radiation from the three above-mentioned strong earthquakes are in good 

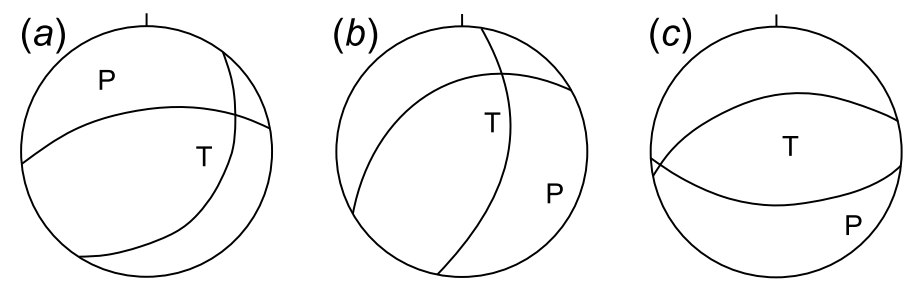

Fig. 6. EFM of $\mathrm{K} \geq 15$ seismic events: (a) - Isfara-Batken (1977); (b) - Pap (1984); (c) - Kochkorat (1992) (EFM Catalogues of the IS NAS KR).

Рис. 6. МОЗ с К $\geq 15:$ ( $a)$ - Исфара-Баткенское 1977 г.; (b) - Папское 1984 г.; (c) - Кочкоратинское 1992 г. (каталоги механизмов очагов землетрясения ИС НАН КР).

agreement with the occurrence times and locations of the large landslides that developed after the earthquakes (see Fig. 4 and Fig. 5).

One more aspect needs to be considered here. It is noted in the introduction that landsliding may take place before strong earthquakes. Based on our concept of the origin of the landslide activity, this phenomenon can be explained by precursors of a seismic event. For example, the hydrogeodynamic parameters of groundwater sources were evidently anomalous before the Papskoe earthquake [Gafurov, 1986].

An earthquake does not occur instantly, like an explosion. It has a long history of preparation and a short-term history of development of a rupture [Brune, 1979; Rebetsky, Guo, 2019]. Earthquake precursors, such as quiescence zones, changes in parameters of electric and magnetic fields, changes in the hydrodynamic parameters of groundwater sources, give evidence of changes in the state of stresses. Additional stresses may develop due to the presence of fluids that move in response to external forces (e.g. gravitational interaction of the Earth and other planets), which impacts can last for several months, as well as for several years [Rebetsky, 2006]. The regional stresses are par- tially released after a major rupture is completely formed. Later on, stresses are redistributed and releases at the local level, which is manifested by aftershocks and landslides [Kuchay et al., 2017].

Thus, redistribution of stresses is the mechanism of the effects of strong earthquakes on landslides. This mechanism is active both before an earthquake (when precursors give evidence of accumulation of stresses in the zone of a future strong earthquake) and after the earthquake (i.e. redistribution of a part of the released regional stresses on the local level).

\section{Precipitation}

It is known that precipitation is one of the most important triggers of the landslide activity. According to the published data, 50-60\% of landslides result from excessive annual precipitation. In Kyrgyzstan, a $20 \%$ increase of the long-term average annual precipitation values does not influence the landslide activity in any way [Meleshko et al, 2002]. Precipitation leads to massive landsliding when the long-term average annual precipitation values are exceeded by $40 \%$ or more. In the 50-year cycle (1950-2000), the landslide activity increased in the mountainous frame of the Fergana basin in 1954, 1969, 1978 and 1994 [Meleshko et al., 2002]. In his calculations, A.V. Meleshko did not take into account the volume of landslides and referred only to their total number, including new landslides, landslides showing major shifting, landslides with secondary displacements, and stabilized landslides.

In this study, we used the data from meteorological stations Ak-Terek, Jalal-Abad, Salamalik and Gulcha (National Hydrometeorological Agency of Kyrgyzstan) (see Fig. 4, a). Simultaneous increases and decreases of the precipitation amounts were recorded by these stations. The records of the Ak-Terek and Salamalik stations show generally higher precipitation amounts, as compared to the records of the Gulcha and Jalal-Abad
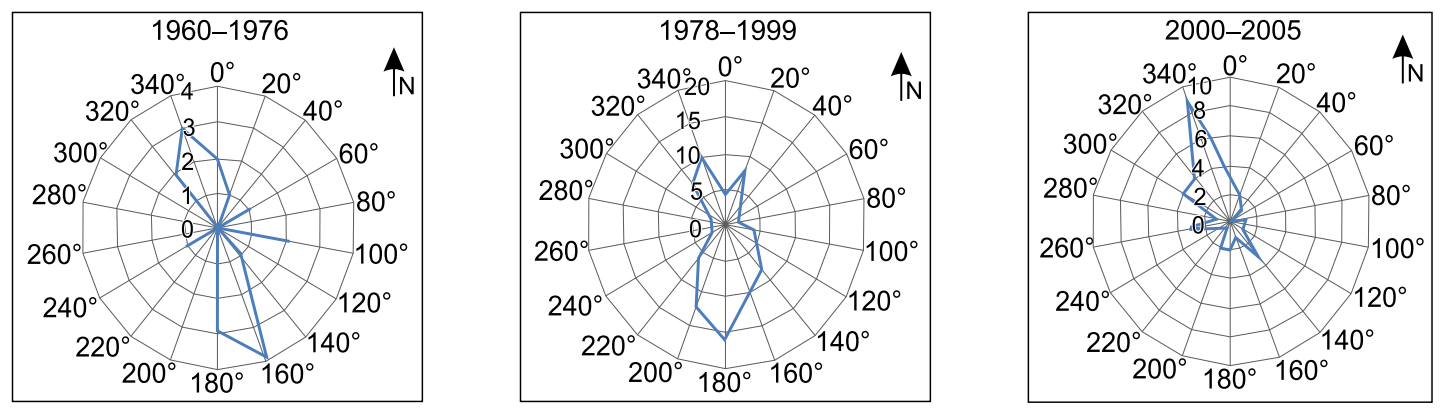

Fig. 7. P-axis azimuth for Site 3.

Рис. 7. Рапределение азимута оси сжатия Р для площадки № 3. 
stations. In 1969 (the year of increased landslide activity in the study area), the annual precipitation amounts recorded by all the stations, except Gulcha station, exceeded the long-term average annual value by more than $40 \%$. Landslide activity bursts occurred in 1954 and 1994, i.e. in a year after of $40 \%$ excessive precipitation amounts recorded by the Dzhalal-Abad and Salamalik stations. However, the burst of 1978 cannot be explained by excessive precipitation - as it occurred nine years after normal annual values. However, significantly excessive precipitation in 1987 and 1998 was not accompanied by any increase of the landslide activity [Meleshko et al, 2002]. According to [Ibatulin, 2011], many new landslide ruptures formed in 1987-1988. In the period from 1955 to 2005 , a $40 \%$ excessive precipitation was observed by each station no more than three to four times. The landslide occurrence, however, was more frequent.

It is noted in [Meleshko, 2002; Ibatulin, 2011; Niyazov, Nurtaev, 2015; Niyazov, 2017] that precipitation can accumulate in the period from October to March, inclusively, and this factor needs to be taken into account. Excessive precipitation values in these months were recorded more frequently than the excessive long-term average annual values. Moreover, the longterm precipitation values were exceed in some months, although the annual precipitation values were normal. In this study, we considered the annual, winter and monthly excessive precipitation values.

On Site 1, large landslides occurred in the first half of the year, especially in the summer months. The AkTerek station recorded three cases of a $40 \%$ excess of the long-term average annual precipitation amount. The average annual, winter, and summer precipitation values were exceeded in 1969, and landslides occurred on the site. In 1987 and 1998, there were no large landslides on Site 1. It should be noted that six landslides (out of 12 on this site) occurred in normal atmospheric conditions.

On Site 2, more than half of the landslides occurred from March to May. The landslide activity is generally increased in these months. Only two out of ten large landslides on Site 2 can be related to precipitation there were heavy rainfalls in April 1994, and the annual precipitation amount was exceeded in 2003. Other eight landslides occurred when monthly precipitation amounts were normal and even in the autumn months.

On Site 3, landslides mostly occurred in the spring months. A $40 \%$ excess of the long-term average annual precipitation amounts was recorded in 1987, 1998 and 2003. In some years, the annual precipitation amounts were normal, but the monthly precipitation values were exceeded in the winter months and in March and April. In fact, out of 11 years with landslides on Site 3, there were no heavy rain- and snowfalls only in three years, 1982, 1983 and 1994. It should be also men- tioned that many large landslides (including the largest one, $16 \mathrm{mln} \mathrm{m}^{3}$ ) developed on the ancient landslide bodies located at the eastern side of Site 3. The landslides developed on hill slopes composed of the Cretaceous sediments (red sandstones, aleurolites, variegated clays, sandstones interbedded with marl, limestone and gypsum). The properties of such rocks - high absorption and swelling capacity - are favorable for landsliding surface deformation. Taking into account that the above-mentioned landslides, without exception, occurred in conditions of a $40 \%$ excess of the precipitation amount, there are grounds to conclude that atmospheric precipitation played a significant role and caused an increase of the landslide activity as the physical properties of the rocks on the hill slopes were favourable for landsliding.

In search of correlations between the landslide occurrence times with the precipitation amounts, we also used the P-axis plunge in the EFM solutions for the earthquakes closest in time. It was revealed that, regardless of weather conditions, the $\mathrm{P}$-axis angle to the horizontal plane was significant (with the exception of $1988,6^{\circ}$ ).

In Fig. 8, the locations of the landslides on Site 1 (1988) and Site 3 (1987-1988) relative to active faults give evidence that the earthquakes and landslides are directly related to displacements along the fault. The landslides on Site 3 were possibly triggered by heavy rainfalls. On Site 1, however, no excessive precipitation was observed in 1988.

The above analysis does not reveal any unambiguous relationship between the landslide activity and heavy rainfall. Large landslides due to heavy rainfall amount of $50 \%$ on Site 1 and less than $50 \%$ on Site 2. Furthermore, it must be noted that the landslides related to heavy rainfalls on Site 3 developed on the hill slopes covered with Cretaceous sediments.

The distribution of some 1,500 landslides triggered by the $2016 \mathrm{Mw} 7.1$ Kumamoto earthquake in Japan has been recently investigated [Specht et al., 2019]. It is reported that the low-frequency seismic radiation pattern generally correlates with the distribution of landslides; however, the landslide distribution or orientation (aspect) cannot be sufficiently explain by any of landslide susceptibility factors, including hill slope inclination, median amplification factor (MAF) of ground shaking, lithology, land cover, and topographic wetness. It is worth noting that the need to consider the directness of seismic sources radiation was emphasized in [Strom et al., 2005].

\section{CONCLUSION}

Based on the previously obtained results and the analysis of the EFM parameters by seismic burst cycles 


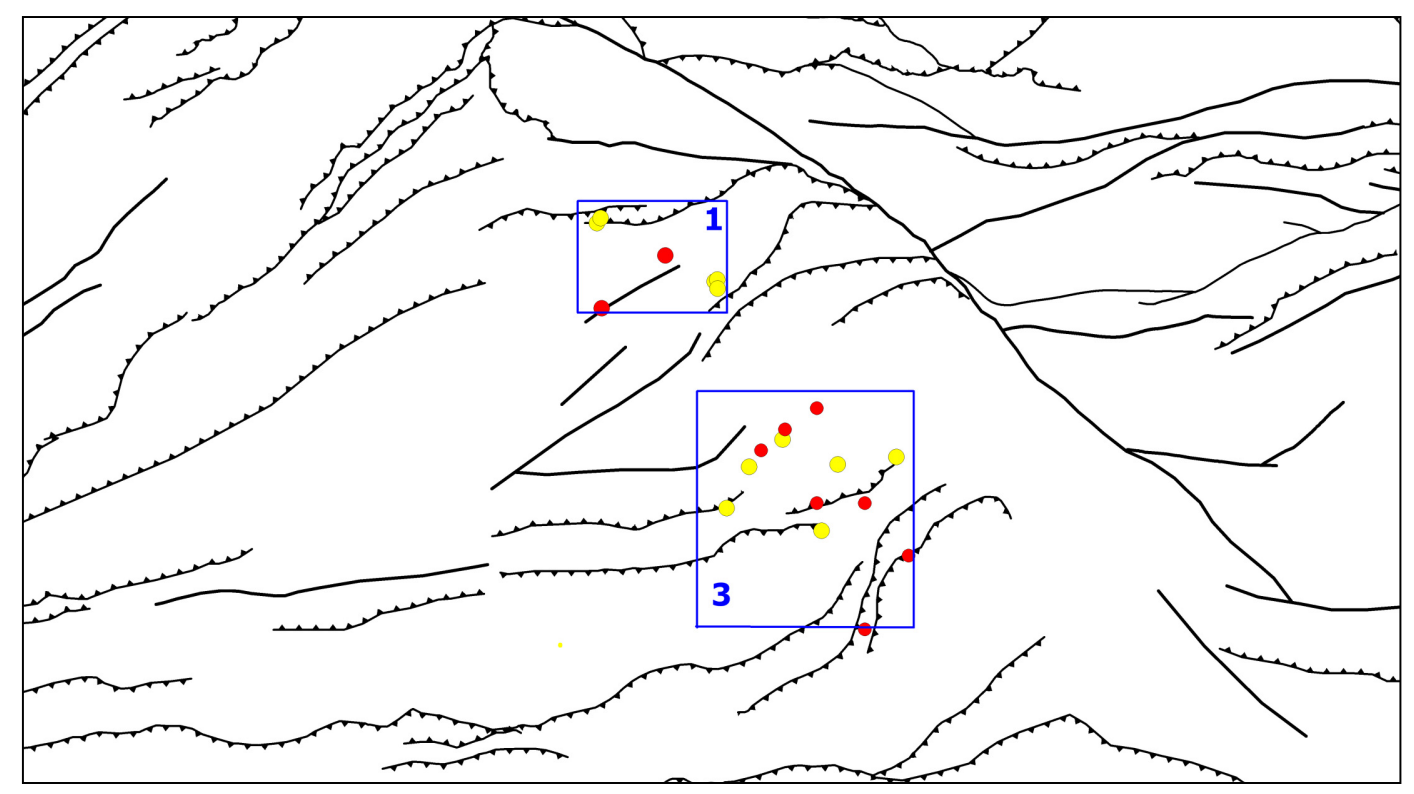

Fig. 8. Map of earthquake epicenters (red circles) and landslide locations (yellow circles) on Site 1 in 1988 and Site 3 in 1987-1988. Active faults after [Mikolaichuk, 2009].

Рис. 8. Карта эпицентров землетрясений (красные кружочки) и оползней (желтые кружочки) за 1987-1988 гг. на площадках № 1 и № 3. Активные разломы по данным [Mikolaichuk, 2009].

(see Fig. 1, 2), this paper provides a description of the landslide activity and seismicity, which is a result of our 10-year research of the study area.

Our study results give grounds to conclude that natural stresses in the crust are the major cause of the landslide activity and seismicity in the mountainous regions. Each 'burst' cycle is characterized by a specific $\mathrm{P}$-axis azimuth (AzP). During the cycle, migration of $\mathrm{K} \geq 12$ earthquake epicenters takes place in a specific straight direction that corresponds to the P-axis azimuth in accordance with the laws of mechanics. Changes in the P-axis azimuth lead to changes in the direction of migration of the earthquake epicenters. Landslides occur when, after some stabilization of the horizontal position of the $\mathrm{P}$ axis (which can last for several months or a few years), the P-axis azimuth deviates from the horizontal plane, i.e. horizontal compression is reduced. In the future studies (pending a proper monitoring infrastructure in the study area), it is reasonable to give special attention to this feature - it can be referred to as a medium-term precursor of the landslide activity.

Our data show that during certain intervals, landslides occurred only on certain sites. This is explained by the position of the internal structure with respect to the direction of the stress axes (similar to positioning of earthquake epicenters in each seismic 'burst' with respect to the corresponding $\mathrm{P}$-axis azimuth).

The mechanism of the impact of strong earthquakes on the occurrence of landslides is redistribution of stresses. In case of a strong earthquake, regional stres- ses are partially released by fracturing of the crust, which leads to redistribution of local stresses and occurrence of landslides and aftershocks.

Therefore, the character of seismic radiation of the past strong earthquake need to be properly considered as it can show places of the landslide activity in case of potential catastrophic seismic events in future. It is stated in [Niyazov, Nurtaev, 2015; Niyazov, 2017] that landslides caused by remote earthquakes occur suddenly and unpredictably. Nonetheless, our study results suggest a possibility of their forecasting, if a reliable infrastructure is available for monitoring of natural stresses.

The landslide activity is considerably dependent on precipitation and the features of hill slopes that are prone to landsliding (inclination, aspect, physical properties of sediments covering the hill slopes, topographic wetness, etc.). Taking these features into account can become possible after zoning of the study area on the basis of detailed geological, geophysical and seismological data on the internal structure of the upper crust. Clarification of the features of every site will provide for developing standard models to further investigate the landslide activity.

The above conclusions and assumptions concerning the origin of the landslide activity in seismically active areas allow us to outline research directions for future studies. The goal is to develop the methodology of landslide-hazard mapping (similar to seismic zoning mapping). The main objectives are as follows:

(1) Zoning of the study area with respect to the internal structure of the upper crust; 
(2) Studying the recent geodynamics and the state of crustal stresses by geological, geophysical and seismological methods. It should be noted in this study we used only azimuth and plunge of the principal compression stress axis of EFM. The cataclastic analysis method (CAM) [Rebetsky, 2007; Rebetsky et al., 2017] provides for a more detailed investigation of natural stresses on the basis of EFM data, and it has been already applied to study the Northern Tien Shan [Rebetsky, Kuzikov, 2016; Rebetsky et al., 2016];

(3) Instrumental monitoring of landslides in the zones that differ in the structure of the upper crust (establish and survey landslide monitoring stations on the specified sites. This is necessary for compare the time of the occurrence of the landslide and earthquake, since at present time an earthquake is recordable with an accuracy of milliseconds, while landslide move- ments are recorded with an accuracy of several days, at best, or may remain undetected);

(4) Analysis of preparation and consequences of strong earthquakes that took place in the study area in comparison with the landslide activity The CAM is also useful in this respect [Rebetsky, 2007; Rebetsky et al., 2012]).

\section{ACKNOWLEDGMENTS}

The authors are grateful to Yuri L. Rebetsky for supporting our studies and providing valuable comments to this paper. The authors thank Alexander V. Mikolaichuk for his useful comments to the description of the study results, and Khairulla V. Ibatullin for providing the materials and assistance during our study.

\section{REFERENCES}

Abdrakhmatov K.E., Kalmetyeva Z.A., Mikhailova N.N., Sydykov A., Sadykova A.B., Silacheva I.V., Usmanova M.T., Chekhovskaya R.A., 2008. Seismological database of Central Asia as the basis for the study of regional geodynamic processes. In: Geodynamics of intracontinental orogens and geoecological problems. Proceedings of the Fourth International Symposium (Bishkek, June 15-23, 2008). Bishkek, p. 363-367 (in Russian) [Абдрахматов К.Е., Кальметьева З.А., Михайлова Н.Н., Сыдыков А., Садыкова А.Б., Силачева И.В., Усманова М.Т., Чеховская Р.А. Сейсмологическая база данных Центральной Азии как основа изучения региональных геодинамических процессов // Геодинамика внутриконтинентальных орогенов и геоэкологические проблемы: Материалы Четвертого международного симпозиума (15-23 июня 2008 г., г. Бишкек). Бишкек, 2008. С. 363-367].

Abdybachaev U.A., 2015. Unified Database on Landslides of Kyrgyzstan (Final Report, Contract No. 2A/13-1). CentralAsian Institute for Applied Geosciences (CAIAG), Bishkek, 65 p. (in Russian) [Абдыбачаев У.А. Единая база данных об оползнях Кыргызстана (Заключительный отчет по договору № 2А/13-1). ЦАИИЗ: Бишкек, 2015. 65 c.].

Bakirov A.B. (Ed.), 2006. The Earth's Crust and Upper Mantle of the Tien Shan in Connection to Geodynamics and Seismicity. Ilim, Bishkek, 116 p. (in Russian) [Земная кора и верхняя мантия Тянь-Шаня в связи с геодинамикой и сейсмичностью / Ред. А.Б. Бакиров. Бишкек: Илим, 2006, 116 с.].

Bogdanovich K.I., Kark I.M., Korolkov B.Ya. Mushketov D.I., 1911. Earthquakes in the northern ranges of the Tien Shan on December 12, 1910 (04.01.1911). Proceedings of the Geological Committee 30 (4), 329-419 (in Russian) [Богданович К.И., Карк И.М., Корольков Б.Я., Мушкетов Д.И. Землетрясения в северных цепях Тянь-Шаня 12 декабря 1910 года (4.1.1911 г.) // Известия Геологического комитета. 1911. Т. 30. № 4. Р. 329-419].

Brune J.N., 1979. Implications of earthquake triggering and rupture propagation for earthquake prediction based on premonitory phenomena. Journal of Geophysical Research: Solid Earth 84 (B5), 2195-2198. https://doi.org/ 10.1029/JB084iB05p02195.

Chedia O.K., 1986. Morphostructures and Modern Tectogenesis of the Tien Shan. Ilim, Frunze, 312 p. (in Russian) [Чедия О.К. Морфоструктуры и новейший тектогенез Тянь-Шаня. Фрунзе: Илим, 1986. 312 с.].

Dzhanuzakov K.D., Omuraliev M., Omuralieva A., Ilyasov B.I., Grebennikova V.V., 2003. Strong Earthquake of the Tien Shan. Ilim, Bishkek. 215 p. (in Russian) [Джанузаков К.Д., Омуралиев М., Омуралиева А., Ильясов Б.И., Гребенникова В.В. Сильные землетрясения Тянь-Шаня. Бишкек: Илим, 2003. 215 с.].

Gafurov V.G. (Ed.), 1986. The 1984 Pap Earthquake. FAN, Tashkent, 136 p. (in Russian) [Папское землетрясение 1984 г. / Ред. В.Г. Гафуров. Ташкент: ФАН, 1986. 136 с.].

Grin V.P., Ilyasov B.I., Kim N.I., Lopatina T.A., Medzhitova Z.A., Serebryanskaya T.Ya., 1980. Some results of prognostic studies on the Frunze test site. In: Physical processes in earthquake sources. Nauka, Moscow, p. 14-26 (in Russian) [Грин В.П., Ильясов Б.И., Ким Н.И., Лопатина Т.А., Меджитова З.А., Серебрянская Т.Я. Некоторые результаты прогностических исследований на Фрунзенском полигоне // Физические процессы в очагах землетрясений. М.: Наука, 1980. С. 14-26].

Ibatulin Kh.V., 2011. Landslide Monitoring of Kyrgyzstan. Ministry of Emergency Situations of the Kyrgyz Republic, Bishkek, 145 p. (in Russian) [Ибатулин X.В. Мониторинг оползней Кыргызстана. Бишкек: МЧС КР, 2011. 145 с.].

Kalmetyeva Z.A., Berezina A.V., Moldobekova S.K., Torgoev I.A., 2013. Using the national monitoring network of IS NAS KR to study landslides. Herald of NNC RK (2), 116-120 (in Russian) [Кальметьева З.А., Березина А.В., Молдобе- 
кова С.К., Торгоев И.А. Использование национальной сети мониторинга ИС НАН КР для изучения оползней. // Вестник НЯЦ РК. 2013. № 2. С. 116-120].

Kalmetyeva Z.A., Kostyuk A.D., Meleshko A.V., Sycheva N.A., 2010. On the relationship of landslides and earthquakes. Proceedings of the NAS KR (4), 19-27 (in Russian) [Кальметьева З.А., Костюк А.Д., Мелешко А.В., Сычева Н.А. О взаимосвязи оползней и землетрясений // Известия НАН КР. 2010. № 4. С. 19-27].

Kalmetyeva Z.A., Mikolaichuk A.V., Moldobekov B.D., Meleshko A.V., Zhantaev M.M., Zubovich A.V., 2009. Atlas of Kyrgyzstan Earthquakes. CAIAG, Bishkek, 213 p. (in Russian) [Кальметьева З.А., Миколайчук А.В., Молдобеков Б.Д., Мелешко А.В., Жантаев М.М., Зубович А.В. Атлас землетрясений Кыргызстана. Бишкек: ЦАИИЗ, 2009. 213 с.].

Kalmetyeva Z.A., Moldobekov B.D., 2012. Analysis of landslide activity in seismic regions (Tien Shan). Georisk (3), 26-33 (in Russian) [Кальметьева 3.А., Молдобеков Б.Д. Анализ оползневой активности в сейсмичных областях (на примере Тянь-Шаня) // Геориск. 2012. № 3. С. 26-33].

Kalmetyeva Z., Moldobekov B., 2013. Landslides, seismicity and geodynamics in the territory of Kyrgyzstan. In: F. Wu, S. Qi (Eds), Global view of engineering geology and the environment. Taylor \& Francis Group, London, p. 581-586.

Kalmetyeva Z.A., Moldobekov B.D., Torgoev I.A., Volkhin I.I., 2014. Landslides and crustal stress field according to earthquake focal mechanism (Tian Shan). Geofizicheskiye Issledovaniya (Geophysical Research) 15 (2), 47-58 (in Russian) [Кальметьева З.А., Молдобеков Б.Д., Торгоев И.А., Вольхин И.И. Оползневые процессы и поле напряжений земной коры по данным о механизмах очагов землетрясений (на примере Тянь-Шаня) // Геофизические исследования. 2014. Т. 15. № 2. С. 47-58].

Kuchay O.A., Kalmet'eva Z.A., Kozina M.E., Abdrakhmatov K.E., 2017. Stress fields revealed by aftershocks of the strongest earthquakes of Tien Shan. Geodynamics \& Tectonophysics 8 (4), 827-848 (in Russian) [Кучай O.A., Кальметьева З.А., Козина М.Е., Абдрахматов К.Е. Поля напряжений по афтершокам сильнейших землетрясений ТяньШаня // Геодинамика и тектонофизика. 2017. Т. 8. № 4. C. 827-848]. https://doi.org/10.5800/GT-2017-8-40319.

Meleshko A.V., Usupaev Sh.E., Torgoev I.A., 2002. Modern landlides of Kyrgyzstan: retrospective analysis of their development at representative sites. In: Massive rock slope failure: new models for hazard assessment. Abstracts volume of the NATO advanced research workshop (Celano, Abruzzo, Italy, 16-21 June 2002). Celano, p. 97.

Mikolaychuk A.V., 2009. Geodynamics and seismicity of Kyrgyzstan. In: Atlas of Kyrgyzstan earthquakes. CAIAG, Bishkek, 213 p. (in Russian) [Миколайчук А.В. Геодинамика и сейсмичность Кыргызстана // Атлас землетрясений Кыргызстана. Бишкек: ЦАИИЗ, 2009. 213 с.].

Niyazov R.A., 2017. Uzbekistan landslides, state of research and risk mitigation. In: Studies of landslides and their risk mitigation in Central Asia: Proceedings of the UNESCO Conference. Almaty, p. 19-48 (in Russian) [Ниязов Р.A. Оползни Узбекистана, состояние исследований и деятельность по снижению риска // Исследование оползней и снижение их риска в Центральной Азии: Материалы конференции UNESCO. Алматы, 2017. C. 19-48].

Niyazov R.A., Nurtayev B.S., 2015. Deep-focus Hindu Kush earthquakes as a trigger for initiation of liquefaction landslides. In: Analysis, forecast and management of risk threats in the modern world. Proceedings of the 9th International scientific and practical conference. Peoples' Friendship University of Russia, Moscow, p. 36-41 (in Russian) [Ниязов P.A., Нуртаев Б.С. Глубокофокусные Гиндукушские землетрясения как спусковой крючок начала движения оползней разжижения // Анализ, прогноз и управление угрозами риска в современном мире: Материалы 9-й Международной научно-практической конференции. М.: Российский университет дружбы народов, 2015. С. 36-41].

Postoev G.P., 2010. Equations of massif state for landslides formation. Inzhenernaya Geologiya (Engineering Geology) (4), 48-53 (in Russian) [Постоев Г.П. Уравнения состояния массива при формировании оползней // Инженерная геология. 2010. № 4. С. 48-53].

Postoev G.P., Kazeev A.I., 2011. About protection strategy on territories with deep landslides. In: Environmental geosciences and engineering survey for territory protection and population safety. Delegate papers of International Conference EngeoPro-2011. Moscow, p. 342-348.

Rebetsky Yu.L., 2006. Dilitancy, pore fluid pressure and new data on rock masses strength in natural location. In: Yu.G. Leonov (Ed.), Fluids and geodynamics. Nauka, Moscow, p. 120-146. (In Russian) [Ребецкий Ю.Л. Дилатансия, поровое давление флюида и новые данные о прочности горных массивов в естественном залегании // Флюиды и геодинамика / Ред. Ю.Г. Леонов. М.: Наука, 2006. С. 120-146].

Rebetsky Yu.L., 2007. Tectonic Stresses and Strength of Mountain Ranges. Akademkniga, Moscow, 406 p. (in Russian) [Ребецкий Ю.Л. Тектонические напряжения и прочность горных массивов. М.: Академкнига, 2007. 406 с.].

Rebetsky Yu.L., Guo Y.-S., 2019. From natural stresses in seismic zones to predictions of mega earthquake nucleation zones. Pure and Applied Geophysics (in press). https://doi.org/10.1007/s00024-019-02128-0.

Rebetsky Yu.L., Kuchai O.A., Sycheva N.A., Tatevossian R.E., 2012. Development of inversion methods on fault slip data: Stress state in orogenes of the Central Asia. Tectonophysics 581, 114-131. https://doi.org/10.1016/j.tecto.2012. 09.027 .

Rebetsky Yu.L., Kuzikov S.I., 2016. Active faults of the northern Tien Shan: tectonophysical zoning of seismic risk. Russian Geology and Geophysics 57 (6), 967-983. https://doi.org/10.1016/j.rgg.2016.05.004.

Rebetsky Yu.L., Kuzikov S.I., Sycheva N.A., 2017. Active faults of the Northern Tien Shan and stress state of the Earth's crust. In: Problems of geodynamics and geoecology of intracontinental orogenes. Abstracts of the VII International 
Symposium. Research Station of RAS, Bishkek, p. 262-263 (in Russian) [Ребецкий Ю.Л., Кузиков С.И., Сычева Н.А. Активные разломы Северного Тянь-Шаня и напряженное состояние земной коры // Проблемы геодинамики и геоэкологии внутриконтинентальных орогенов: Тезисы докладов VII Международного симпозиума. Бишкек: Научная станция РАН, 2017. С. 262-263].

Rebetsky Yu.L., Sycheva N.A., Sychev V.N., Kuzikov S.I., Marinin A.V., 2016. The stress state of the northern Tien Shan crust based on the KNET seismic network data. Russian Geology and Geophysics 57 (3), 387-408. https://doi.org/ 10.1016/j.rgg.2016.03.003.

Seismic Zoning of the USSR Territory (SR-78), 1980. Nauka, Moscow, 399 p. (in Russian) [Сейсмическое районирование территории СССР (СР-78). М.: Наука, 1980. 399 с.].

Specht S., Ozturk U., Veh G., Cotton F, Korup O., 2019. Effects of finite source rupture on landslide triggering: The 2016 Mw 7.1 Kumamoto earthquake. Solid Earth 10 (2), 463-486. https://doi.org/10.5194/se-10-463-2019.

Strom A.L., Abdrakhmatov K.E., Kozhogulov K.Ch., Nikolskaya O.V., 2005. Tectonics, seismicity and rock collapselandslide processes. In: Modern geodynamics of the areas of intracontinental collision mountain formation (Central Asia). Nauchny Mir, Moscow, p. 290-299 (in Russian) [Стром А.Л., Абдрахматов К.Е., Кожогулов К.Ч., Никольская O.B. Тектоника, сейсмичность и обвально-оползневые процессы // Современная геодинамика областей внутриконтинентального коллизионного горообразования (Центральная Азия). М.: Научный мир, 2005. С. 290-299].

Torgoev I., Aleshin Y., Torgoev A., 2011. Monitoring of landslides in the Kyrgyzstan. In: Environmental geosciences and engineering survey for territory protection and population safety. Delegate Papers of International Conference EngeoPro-2011. Moscow, p. 379-383.

Yudakhin F.N., Kalmetyeva Z.A., 1994. Relationship between strong earthquakes of High Asia. Doklady AN 335 (2), 225-231 (in Russian) [Юдахин Ф.Н., Кальметьева З.А. Взаимосвязь сильных землетрясений Высокой Азии // Доклады AH. 1994. Т. 335. № 2. С. 225-231].

\section{Zoya A. Kalmet'eva}

Candidate of Physics and Mathematics, Senior Researcher

Central-Asian Institute for Applied Geosciences

73/2 Timur Frunze street, Bishkek 720027, Kyrgyzstan

\e-mail: z.kalmetyeva@caiag.kg

(iD) https://orcid.org/0000-0001-5172-3741

Bolot D. Moldobekov

Candidate of Geology and Mineralogy, co-Director

Central-Asian Institute for Applied Geosciences

73/2 Timur Frunze street, Bishkek 720027, Kyrgyzstan

e-mail: b.moldobekov@caiag.kg

(iD) https://orcid.org/0000-0002-9845-2675

\section{Ulan A. Abdybachaev}

Central-Asian Institute for Applied Geosciences

73/2 Timur Frunze street, Bishkek 720027, Kyrgyzstan

e-mail: u.abdybachaev@caiag.kg

(iD) https://orcid.org/0000-0001-7591-1042

\section{Зоя Арслановна Кальметьева}

канд. физ.-мат. наук, с.н.с.

Центрально-Азиатский институт прикладных исследований Земли 720027, Бишкек, ул. Тимура Фрунзе, 73/2, Кыргызстан

Болот Дуйшеналиевич Молдобеков

канд. геол.-мин. наук, содиректор

Центрально-Азиатский институт прикладных исследований Земли 720027, Бишкек, ул. Тимура Фрунзе, 73/2, Кыргызстан

\section{Улан Асылбекович Абдыбачаев}

Центрально-Азиатский институт прикладных исследований Земли 720027, Бишкек, ул. Тимура Фрунзе, 73/2, Кыргызстан 